B I O S C I E N C E

J O U R N A

\title{
ALLOMETRIC EQUATIONS TO ESTIMATE THE LEAF AREA OF Psychotria colorata (WILLD. EX SCHULT.) MÜLL.ARG.
}

Psychotria colorata (WILLD. EX SCHULT) MULLARG.

\author{
João Everthon da Silva RIBEIRO ${ }^{1}$ (D), Francisco Romário Andrade FIGUEIREDO² (D), \\ Ester dos Santos COÊLHO ${ }^{(i)}$, Marlenildo Ferreira MELO (D)
}

\footnotetext{
${ }^{1}$ Private Pratice, Mari, Paraíba, Brazil.

2 Postgraduate Program in Phytotechnics, Federal Rural University of the Semi-Arid, Mossoró, Rio Grande do Norte, Brazil.
}

Corresponding author:

João Everthon da Silva Ribeiro

Email: j.everthon@hotmail.com

How to cite: RIBEIRO, J.E.S., et al. Allometric equations to estimate the leaf area of Psychotria colorata (Willd. Ex Schult.) Müll.Arg. Bioscience Journal. 2021, 37, e37076. https://doi.org/10.14393/BJ-v37n0a2021-53711

\begin{abstract}
Estimating leaf area using non-destructive methods from regression equations has become a more efficient, quick, and accurate way. Thus, this study aimed to propose an equation that significantly estimates the leaf area of Psychotria colorata (Rubiaceae) through linear leaf dimensions. For this purpose, 200 leaves of different shapes were collected, and length (L), width (W), product of length by width (L.W), and real leaf area (LA) of each leaf blade were determined. Then, equations were adjusted for predicting leaf area using simple linear, linear (0.0), quadratic, cubic, power, and exponential regression models. The proposed equation was selected according to the coefficient of determination $\left(R^{2}\right)$, Willmott's agreement index (d), Akaike's information criterion (AIC), mean absolute error (MAE), mean squared error (RMSE) and BIAS index. It was noted that the equations adjusted using L.W met the best criteria for estimating leaf area, but the equation LA $=0.59 *$ L.W from linear regression without intercept was the most suitable. This equation predicts that $59 \%$ of leaf area is explained by L.W. Concluding, the leaf area of $P$. colorata can be estimated using an allometric equation that uses linear leaf blade dimensions.
\end{abstract}

Keywords: Allometric equations. Leaf blade. Modeling. Perpétua-do-mato. Rubiaceae.

\section{Introduction}

Popularly known as "Perpetua-do-mato" and "repolho", Psychotria colorata (Rubiaceae) is an understory shrub, $1.0 \mathrm{~m}$ meter height, that owns simple leaves, pink or purple flowers, and elliptical and blue fruits (Taylor et al. 2007; Vicentini et al. 2016). It is a native and non-endemic species widely distributed in South America, occurring in Guyana, Venezuela, and North, Northeast, and Midwest regions of Brazil (Zappi et al. 2015). The plant is of economic importance and used mainly by traditional populations as a medicinal plant. Due to alkaloids in its leaves, flowers, fruits, and roots, the plant has analgesic properties, being used mainly for ear treatments and abdominal pain alleviation (Matsuura et al. 2013; Souza et al. 2013; Moura and Maruo 2014; Skirycz et al. 2016).

Given the importance of $P$. colorata, ecophysiological studies on growth and propagation of this species become necessary. This way, estimating leaf area is essential to study plant growth and development because leaves directly influence on photosynthetic efficiency, gas exchange, biotic and abiotic stress regulation (Benincasa 2003; Spann and Heerema 2010; Candido et al. 2013).

Leaf area can be determined through destructive (direct) and non-destructive (indirect) methods (Malagi et al. 2010; Sousa et al. 2015). Direct methods are simple and precise, but require more time to be 
performed, in addition to lead to plant destruction (Leite et al. 2017). On the other hand, indirect methods have become as efficient as direct methods, in addition to becoming more practical and accurate, without destroying the sample and allowing many measurements on the same plant at a given time (Pompelli et al. 2012; Sarker et al. 2013). Thus, regression equations have been used to estimate leaf area using linear dimensions of leaves, that is limb length and width (Zhang and Pan 2011).

The non-destructive method was used to estimate leaf area in many medicinal plants, such as Crotalaria juncea L. (Carvalho et al. 2017a), Rosa hybrida L. (Gao et al. 2012), Calotropis procera (Aiton) W. T. Aiton. (Ferreira et al. 2015), Solanum melongela L. (Hinnah et al. 2014), Brassica napus L. (Tartaglia et al. 2016), Plectranthus ornatus Codd. (Silva et al. 2017), Commelina difusa Burm.f. (Carvalho et al. 2017b), Erythroxylum citrifolium A.St.-Hil. (Ribeiro et al. 2019a) and Erythroxylum simonis Plowman (Ribeiro et al. 2018a). Similarly, this study aimed to obtain a regression equation that meaningfully estimates leaf area of Psychotria colorata from linear dimensions of leaf blades.

\section{Material and Methods}

The research was conducted at the Mata do Pau-Ferro Study Park, $\left(6^{\circ} 58^{\prime} 12^{\prime \prime} \mathrm{S}, 35^{\circ} 42^{\prime} 15^{\prime \prime} \mathrm{W}\right)$, in the municipality of Areia, Paraíba state, Northeast region, Brazil (Figure 1). The municipality is situated in the microregion of Brejo Paraibano, Agreste mesoregion, reaching between 400 and $600 \mathrm{~m}$ in altitude, average air temperature of $22{ }^{\circ} \mathrm{C}$ and average annual precipitation of approximately $1,400 \mathrm{~mm}$ (Ribeiro et al. 2018b). The region's climate is classified as Aw ', according to Peel et al. (2007), being tropical hot and humid with autumn-winter rains.

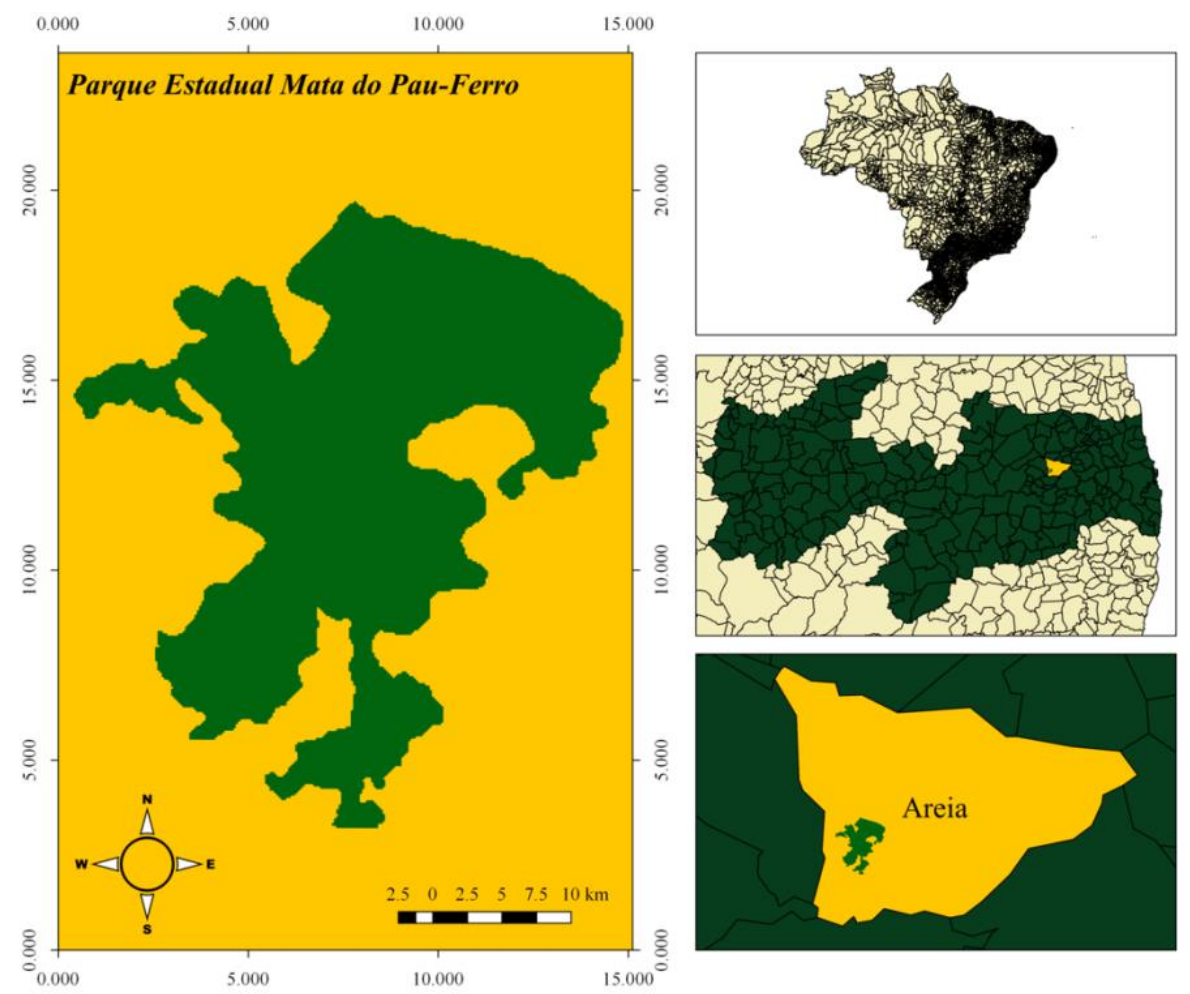

Figure 1. Location of Parque Estadual Mata do Pau-Ferro, Areia, Paraíba, Brazil. Source: João Everthon da Silva Ribeiro (2020).

For measurement, 200 leaves of different physiognomies were collected in 25 plants from $P$. colorata, selecting those healthy limbs, without biotic and abiotic injuries (Schmildt et al. 2014). The leaves were packed in plastic bags inside ice-filled containers to prevent excessive water loss, then transported to the Laboratory of Vegetal Ecology, at the Federal University of Paraíba, for further analysis. At the laboratory, length (L) and width (W) of each leaf blade were measured using a digital caliper, as shown in Figure 2, and the product of these two variables was then calculated (L.W). Also, to obtain the real leaf area (LA), the 200 leaves were photocopied at $300 \mathrm{dpi}$ resolution using a scanner, and the images were processed using the ImageJ ${ }^{\circledast}$ program (Collins 2007), a public domain software. 


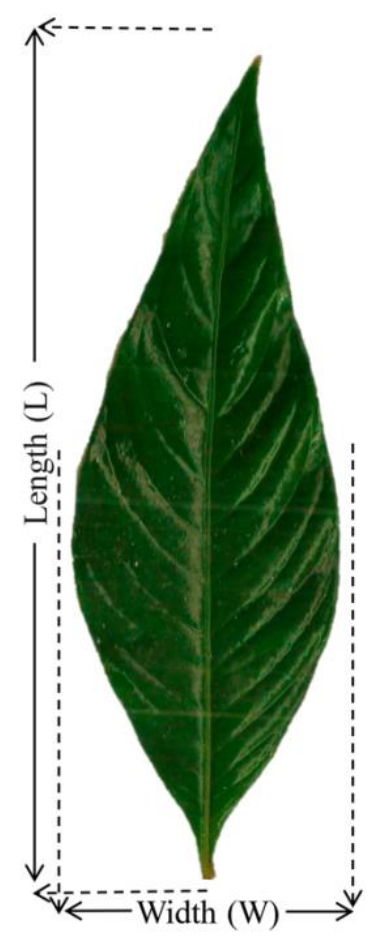

Figure 2. Length and width of leaf blades used to estimate leaf area of $P$. colorata.

A preliminary descriptive analysis for length (L), width (W), product of length by width (L.W), and leaf area (LA) from the 200 leaf blades was performed, wherewith minimum value, maximum value, mean, median, total amplitude, variance, standard error, standard deviation, and coefficient of variation for each variable were calculated.

To find an equation that accurately estimates the leaf area of $P$. colorata, linear, linear without intercept (0.0), quadratic, cubic, power, and exponential regressions models were fitted using the linear dimensions of the leaf blades, as described in Table 1. Afterward, the regression equation that best estimate the leaf area was selected according to highest determination coefficient $\left(R^{2}\right)$ and highest Willmott index $(d)$ (equation 1) (Willmott et al. 1981), lowest mean absolute error (MAE) (equation 2), lowest Akaike information criterion (AIC) (equation 3) (Akaike 1974), and lowest root mean square error (RMSE) (equation 4) (Janssen and Heuberger 1995); and BIAS index closest to zero (equation 5) (Leite and Lima 2002). Statistical analyses were performed in $R^{\circledast}$ software v.3.5.1.

$$
\begin{aligned}
& d=1-\frac{\sum_{i=1}^{n}\left(\hat{y}_{\mathrm{i}}-y_{\mathrm{i}}\right)^{2}}{\sum_{i=1}^{n}\left(\left|\hat{y}_{\mathrm{i}}\right|+\left|y_{\mathrm{i}}^{\prime}\right|\right)^{2}} \\
& \mathrm{MAE}=\frac{\sum_{i=1}^{n}|\hat{y} i-y i|}{n} \\
& A I C=-2 \ln L(x \backslash \hat{\theta})+2(p) \\
& R M S E=\sqrt{\frac{\sum_{i=1}^{n}(\hat{y} i-y i)^{2}}{n}} \\
& B I A S=\frac{\sum_{i=1}^{n}(\hat{y} i-y i)}{\sum_{i=1}^{n}(y i)}
\end{aligned}
$$

$\hat{y}_{\mathrm{i}}$ : estimated leaf area values; $y_{\mathrm{i}}$ : observed leaf area values; $\bar{y}_{\mathrm{i}}$ : mean of observed values; $\hat{y}_{\mathrm{i}}^{\prime}=\hat{y}_{\mathrm{i}}-$ $\bar{y} ; y_{i}^{\prime}=y_{i}-\bar{y} ; L(x \backslash \hat{\theta})$ : maximum likelihood function, defined as the product of density function; $p: \mathrm{n}^{\circ}$ of model parameters; $n$ : total number of observations. 
Table 1. Regressions models used to estimate the leaf area (LA) of $P$. colorata using linear dimensions (L, W and L.W) of its leaf blades.

\begin{tabular}{cc}
\hline Model & Equation \\
\hline Linear & $L A=a+b^{*} L$ \\
Linear & $L A=a+b^{*} W$ \\
Linear & $L A=a+b^{*}(L . W)$ \\
Linear without intercept (0.0) & $L A=b^{*}(L . W)$ \\
Quadratic & $L A=a^{*} L^{2}+b^{*} L+L$ \\
Quadratic & $L A=a^{*} W^{2}+b^{*} W+L$ \\
Quadratic & $L A=a^{*}(L . W)^{2}+b^{*}(L . W)+L$ \\
Cubic & $L A=a^{*} L^{3}+b^{*} L^{2}+L^{*} L+d$ \\
Cubic & $L A=a^{*} W^{3}+b^{*} W^{2}+L^{*} W+d$ \\
Cubic & $L A=a^{*}(L . W)^{3}+b^{*}(L . W)^{2}+L^{*}(L . W)+d$ \\
Power & $L A=a^{*} L^{b}$ \\
Power & $L A=a^{*} W^{b}$ \\
Power & $L A=a^{*}(L . W)^{b}$ \\
Exponential & $L A=a^{*} b^{L}$ \\
Exponential & $L A=a^{*} b^{W}$ \\
Exponential & $L A=a^{*} b^{(L . W)}$ \\
\hline
\end{tabular}

\section{Results and Discussion}

Length of limbs ranged from 2.74 to $25.16 \mathrm{~cm}, 10.97 \mathrm{~cm}$ mean and $22.41 \mathrm{~cm}$ amplitude, while width varied from 0.63 to $6.90 \mathrm{~cm}, 3.15 \mathrm{~cm}$ on mean and 6.26 amplitude. Product of length by width varied from 1.81 to $173.77 \mathrm{~cm}^{2}, 41.14 \mathrm{~cm}^{2}$ on mean and $171.96 \mathrm{~cm}^{2}$ amplitude; and real leaf area ranged from 1.37 to $102.64 \mathrm{~cm}^{2}, 24.65 \mathrm{~cm}^{2}$ on mean and $101.27 \mathrm{~cm}^{2}$ amplitude (Table 2).

The lowest coefficients of variation were found for $L(43.38 \%)$ and $W(46.56 \%)$, whereas the highest coefficients were those from L.W (82.49\%) and LA (81.75\%) (Table 2). High values of standard error, total amplitude, standard deviation, and coefficient of variation are fundamental for estimating leaf area through regression models (Levine et al. 2017).

High variation in data meets more representative regression models, thus allowing researchers to measure the plant at different growth stages (Pezzini et al. 2018). Therefore, the number of leaves (200) evaluated in the present study was meaningful for estimating the leaf area of $P$. colorata using dimensions of its leaf blades. Moreover, high variation in product of length by width and real leaf area was also observed in previous studies (Leite et al. 2017; Ribeiro et al. 2018a; Ribeiro et al. 2020a).

Table 2. Minimum, maximum, mean, total amplitude, median, variance, standard deviation, standard error, and coefficient of variation for length (L), width (W), product of length by width (L.W), and real leaf area (LA) of 200 Psychotria colorata leaf blades.

\begin{tabular}{ccccc}
\hline Descriptive statistics & L & W & L.W & 1.375 \\
Minimum & 2.748 & 0.636 & 1.8137 & 173.7781 \\
Maximum & 25.167 & 6.905 & 41.1459 & 24.6517 \\
Mean & 10.972 & 3.1527 & 30.7256 & 18.682 \\
Median & 10.2465 & 2.9985 & 171.9645 & 101.274 \\
Total Amplitude & 22.419 & 6.269 & 1152.096 & 406.1181 \\
Variance & 22.6566 & 2.155 & 33.9425 & 20.1524 \\
Standard Deviation & 4.7599 & 1.468 & 2.4001 & 1.425 \\
Standard Error & 0.3366 & 0.1038 & $82.49 \%$ & $81.75 \%$ \\
\hline Coefficient of Variation & $43.38 \%$ & $46.56 \%$ & &
\end{tabular}

Scatterplots between L, W, L.W, and LA showed different dispersion patterns (Figure 3), indicating that the data fit linear and non-linear regression models, as found in other similar studies (Toebe et al. 2019; Ribeiro et al. 2020b). 

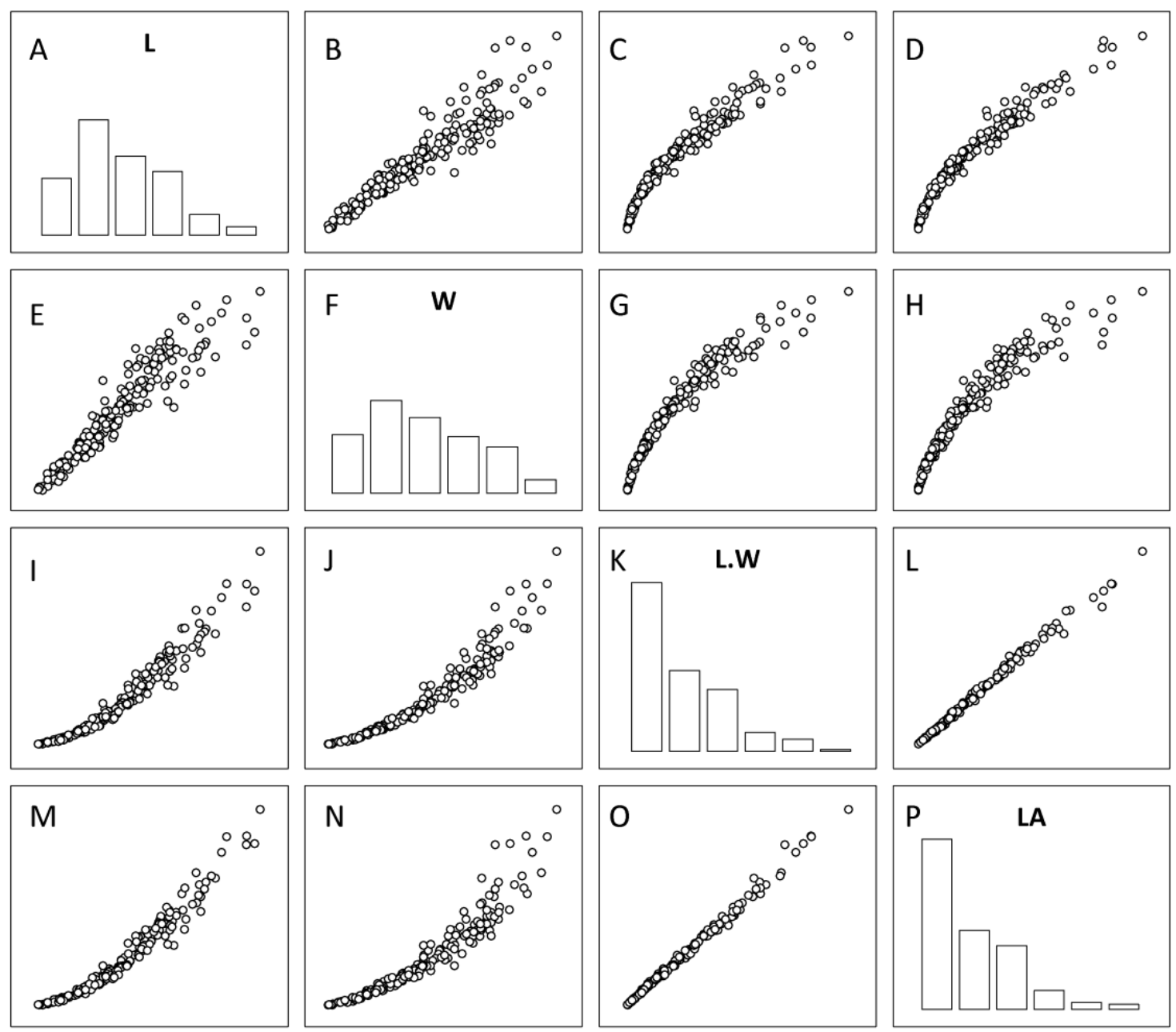

Figure 3. Frequency histogram and scatterplots between length (L), width (W), product of length by width (L.W), and real leaf area (LA) of 200 Psychotria colorata leaf blades. Frequency histogram: A - length; F width; $K$ - product of length by width; $P$ - real leaf area. Scatterplots, relationship between: $B, E-L$ and $W ; C, I-L$ and L.W; D, M - L and LA; G, J-W and L.W; H, N-W and LA; L, O - L.W and LA.

Figure 4 shows the leaf area percentage distribution by different intervals. It was noted that $25 \%$ of the real leaf area was between 10.01 and $20.00 \mathrm{~cm}^{2}$, suggesting that $P$. colorata leaves are medium in size. Ribeiro et al. (2019b), observed that Psychotria carthagenensis Jacq. and Psychotria hoffmannseggiana (Willd. ex Schult.) Müll.Arg., other species from the Rubiaceae family, own leaves of different sizes.

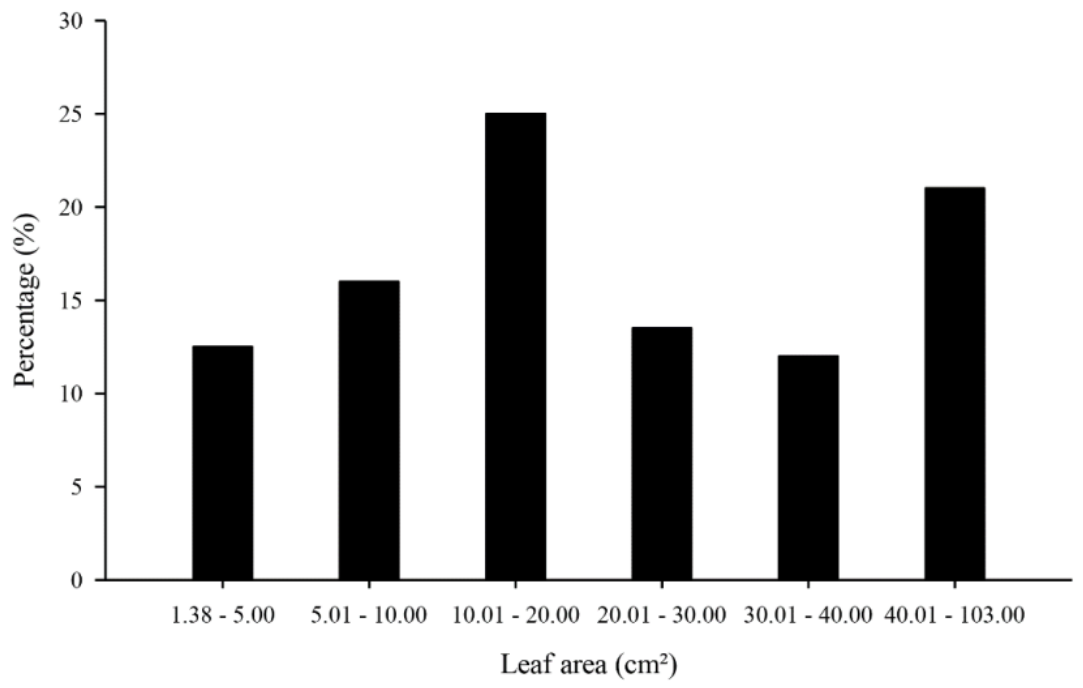

Figure 4. Leaf area percentage distribution of 200 Psychotria colorata leaf blades by different intervals. 
Table 4 shows the equations adjusted using regression models for predicting leaf area using linear dimensions of leaves. All proposed equations meaningfully estimated $P$. colorata leaf area, with high determination coefficients $\left(R^{2}>0.88\right)$. Thus, at least $88 \%$ variation in leaf areas were explained by the proposed alometrics equations. The equations using L.W met the best assumptions for predicting leaf area than those that used $L$ and W, better fitting the regression models (Mota et al. 2014; Assis et al. 2015; Braga et al. 2018; Lucena et al. 2018; Pezzini et al. 2018; Leite et al. 2019; Oliveira et al. 2019a; Ribeiro et al. 2019a). Though, except for the exponential model, that was best fitted using $\mathrm{L}$.

Therefore, among the regressions models studied, the linear model without intercept using L.W showed the highest values determination coefficient $\left(R^{2}=0.9978\right)$, highest Willmott index $(d=0.9987)$, lowest Akaike information criterion ( $\mathrm{AIC}=724.12)$, lowest root mean square error (RMSE $=1.4494)$, lowest mean absolute error $(\mathrm{MAE}=0.8884)$, and BIAS index closest to zero $(0.1084)$ (Table 4$)$. This way, the equation $\mathrm{LA}=0.59 *$ L.W was that best estimated $P$. colorata leaf area, becoming a quick and practical way to do so. Also, this equation predicts that $59 \%$ of the leaf area can be explained by the product between length and width. This same regression model was used to estimate leaf area of other medicinal plants, such as Capsicum annuum L. (LA =0.57*L.W; Padrón et al. 2016), Combretum leprosum Mart. (LA =0.7103*L.W; Candido et al. 2013), , Commelina diffusa Burm.f. (LA = 0.7*L.W; Carvalho et al. 2017b), Crotalaria juncea L. (LA =0.7390*L.W; Carvalho et al. 2017a), , Ceiba glaziovii (Kuntze) K. Schum. (LA = 0.4549*LW; Ribeiro et al. 2020c), and Erythroxylum simonis Plowman (LA = 0.6426*LW; Ribeiro et al. 2018a).

Table 4. Regression models, linear dimensions $(x)$, determination coefficient $\left(R^{2}\right)$, Akaike information criterion (AIC), root mean square error (RMSE), mean absolute error (MAE), Willmott index (d) and BIAS index from linear dimensions of 200 Psychotria colorata leaf blades.

\begin{tabular}{|c|c|c|c|c|c|c|c|c|}
\hline Model & $x$ & $\mathrm{R}^{2}$ & AIC & RMSE & MAE & $d$ & BIAS & Equation \\
\hline Linear & $\mathrm{L}$ & 0.9380 & 1216.90 & 4.9943 & 3.8152 & 0.9838 & 0.4396 & $L A=-20.34+4.10 * L$ \\
\hline Linear & W & 0.8888 & 1333.68 & 6.6876 & 4.6069 & 0.9698 & 0.4986 & $L A=-16.16+12.95 * W$ \\
\hline Linear & L.W & 0.9945 & 733.58 & 1.4993 & 0.9406 & 0.9986 & 0.3678 & $L A=0.29+0.59 * L W$ \\
\hline Linear $(0.0)$ & L.W & 0.9978 & 724.12 & 1.4494 & 0.8884 & 0.9987 & 0.1084 & $\mathrm{LA}=0.59 * \mathrm{LW}$ \\
\hline Quadratic & $\mathrm{L}$ & 0.9673 & 1089.59 & 3.6148 & 2.4738 & 0.9917 & 0.3101 & $\mathrm{LA}=-5.05+1.14 * \mathrm{~L}+0.12 * \mathrm{~L}^{2}$ \\
\hline Quadratic & W & 0.9323 & 1235.30 & 5.2033 & 3.0303 & 0.9823 & 0.3002 & $\mathrm{LA}=1.15+0.31 * \mathrm{~W}+1.86 * \mathrm{~W}^{2}$ \\
\hline Quadratic & L.W & 0.9947 & 732.55 & 1.4880 & 0.8944 & 0.9986 & 0.1642 & $\begin{aligned} \mathrm{LA}= & 0.77+0.56 * \mathrm{LW}- \\
& 0.0002 * \mathrm{LW}^{2}\end{aligned}$ \\
\hline Cubic & $\mathrm{L}$ & 0.9689 & 1082.37 & 3.5324 & 2.2890 & 0.9921 & 0.3597 & $\begin{array}{c}\mathrm{LA}=1.28-0.79 * \mathrm{~L}+0.28 * \mathrm{~L}^{2}- \\
0.004 * \mathrm{~L}^{3}\end{array}$ \\
\hline Cubic & W & 0.9328 & 1234.83 & 5.1713 & 2.9470 & 0.9826 & 0.3125 & $\begin{array}{c}\mathrm{LA}=-2.86+5.04 * \mathrm{~W}+0.32 * \mathrm{~W}^{2}+ \\
0.14 * \mathrm{~W}^{3}\end{array}$ \\
\hline Cubic & L.W & 0.9947 & 726.04 & 1.4497 & 0.8885 & 0.9986 & 0.1169 & $\begin{array}{c}\mathrm{LA}=0.72+0.57 * \mathrm{LW}+ \\
0.0001 * \mathrm{LW}^{2}-0.0000004 * \mathrm{LW}^{3}\end{array}$ \\
\hline Power & L & 0.9670 & 1093.87 & 3.6720 & 2.5129 & 0.9913 & -0.2454 & $\mathrm{LA}=0.26 * \mathrm{~L}^{1.85}$ \\
\hline Power & W & 0.9325 & 1235.42 & 5.2310 & 3.0875 & 0.9823 & 0.4200 & $\mathrm{LA}=2.39 * \mathrm{~W}^{1.88}$ \\
\hline Power & L.W & 0.9945 & 735.56 & 1.4992 & 0.9371 & 0.9986 & 0.1736 & $\mathrm{LA}=0.60 * \mathrm{LW}^{1.00}$ \\
\hline Exponential & $\mathrm{L}$ & 0.9181 & 1289.91 & 5.9944 & 4.8632 & 0.9745 & -0.9643 & $\mathrm{LA}=5.81^{*} 1.13^{\mathrm{L}}$ \\
\hline Exponential & W & 0.9164 & 1284.03 & 5.9070 & 3.9625 & 0.9759 & -0.6288 & $\mathrm{LA}=4.92 * 1.56^{\mathrm{W}}$ \\
\hline Exponential & L.W & 0.9165 & 1361.93 & 5.9070 & 3.9625 & 0.9759 & -0.6288 & $\mathrm{LA}=12.76^{*} 1.01^{\mathrm{LW}}$ \\
\hline
\end{tabular}

Low data dispersion from the regression line indicates that the equation LA $=0.59 * \mathrm{~L} . \mathrm{W}$ can significantly estimate $P$. colorata leaf area (Figure 5). Also, the leaf area estimated by this equation significantly equaled the real leaf area, with 0.9945 determination coefficient $\left(R^{2}\right)$ (Figure 6). This proposed regression equation might contribute to environmental studies that focus on the growth, development, and propagation of $P$. colorata, assisting in the conservation of the species in forest remnants. 


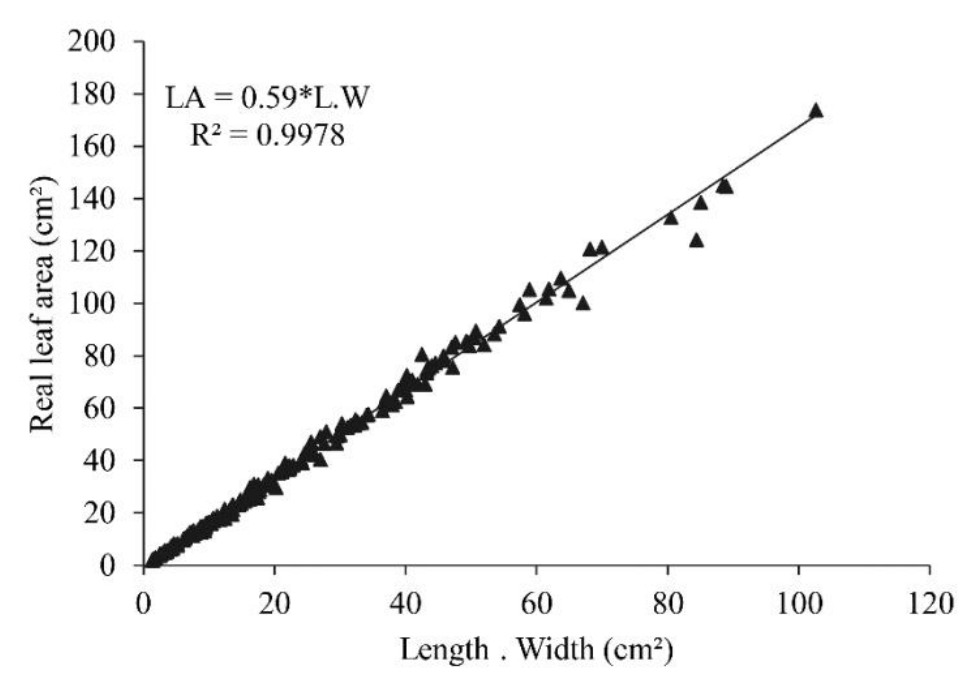

Figure 5. Real leaf area (LA) of Psychotria colorata as a function of the product of length by width (L.W) of leaf blades, using the proposed equation LA $=0.59 * \mathrm{~L} . \mathrm{W}$ for estimating leaf area.

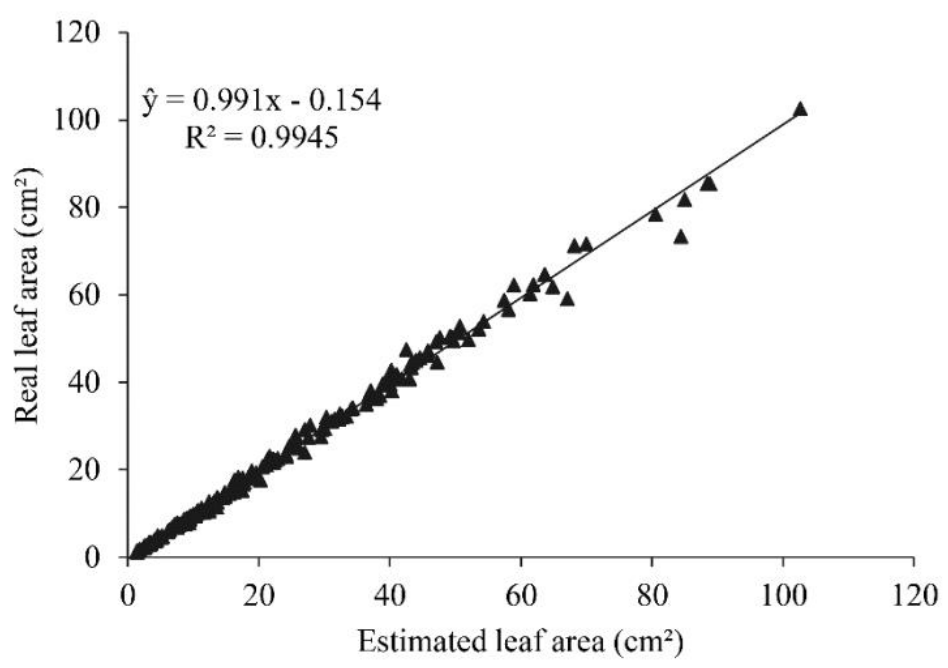

Figure 6. Relationship between real leaf area of Psychotria colorata and estimated leaf area using the proposed equation LA $=0.59 *$ L.W.

\section{Conclusions}

Leaf area of $P$. colorata can be determined by allometric equations, using linear dimensions of the leaf blades.

The equation LA $=0.59 *$ L.W, from the linear regression model without intercept, was that most suitable for estimating $P$. colorata leaf area, as a quick and accurate way.

Regression equations that used the product of length by width (L.W) better estimated the leaf area of the species.

Authors' Contributions: RIBEIRO, J.E.S.: conception and design, acquisition of data, analysis and interpretation of data, drafting the article, critical review of important intellectual content; FIGUEIREDO, E.S.: acquisition of data, drafting the article, and critical review of important intellectual content; COÊLHO, E.S.: drafting the article, and critical review of important intellectual content; MELO, M.F.: critical review of important intellectual content. All authors have read and approved the final version of the manuscript.

Conflicts of Interest: The authors declare no conflicts of interest.

Ethics Approval: Not applicable.

Acknowledgments: The authors would like to thank the funding for the realization of this study provided by the Brazilian agency CAPES (Coordenação de Aperfeiçoamento de Pessoal de Nível Superior - Brasil), Finance Code 001. 


\section{References}

AKAIKE, H. A new look at the statistical model identification. IEEE Transactions on Automatic Control. 1974, 19(6), 716-723. https://doi.org/10.1109/tac.1974.1100705

ASSIS, J.P., et al. Estimação da área foliar da "jitirana" (Merremia aegyptia (L.) Urban), através de modelos de regressão para Mossoró - RN. Revista Verde de Agroecologia e Desenvolvimento Sustentável. 2015, 10(2), 75-81. https://doi.org/10.18378/rvads.v10i4.3872

BENINCASA, M.M.P. Análise de crescimento de plantas: noções básicas. Jaboticabal: FUNEP, 2003.

BRAGA, N.S., et al. Mathematical models for teak foliar area estimation (Tectonas grandis L. f.). Nucleus. 2018, 15(2), 331-339. https://doi.org/10.3738/1982.2278.2910

CANDIDO, W.S., et al. Modelo para estimar a área foliar de Combretum leprosum Mart. Acta Agronómica. 2013, 62(1), 37-41.

CARVALHO, J.O., et al. Leaf area estimation from linear measurements in different ages of Crotalaria juncea plants. Anais da Academia Brasileira de Ciências. 2017a, 89(3), 1851-1868. https://doi.org/10.1590/0001-3765201720170077

CARVALHO, L.B., ALVES, E.A. and BIANCO, S. Modelo não destrutivo para estimar a área foliar de Commelina diffusa. Planta Daninha. 2017b, 35, 1-5. https://doi.org/10.1590/S0100-83582017350100088

COLLINS, T.J. ImageJ for microscopy. BioTechniques. 2007, 43(1), 25-30. https://doi.org/10.2144/000112517

Ferreira, M.L.A., et al. Determinação da área foliar da flor de seda (Calotropis procera) no sertão paraibano. Agropecuária Científica no Semiárido. 2015, 11(1), 53-55. https://doi.org/10.30969/acsa.v11i1.610

GAO, M., et al. Estimation of leaf area for large scale phenotyping and modeling of rose genotypes. Scientia Horticulturae. 2012, 138, 227-234. https://doi.org/10.1016/j.scienta.2012.02.014

HINNAH, F.D., et al. Estimativa da área foliar da berinjela em função das dimensões foliares. Bragantia. 2014, 73(3), 213-218.

https://doi.org/10.1590/1678-4499.0083

JANSSEN, P.H.M. and HEUBERGER, P.S.C. Calibration of process-oriented models. Ecological Modelling. 1995, 83(1-2), 55-66. https://doi.org/10.1016/0304-3800(95)00084-9

LEITE, H.G. and ANDRADE, V.C.L. Um método para condução de inventários florestais sem o uso de equações volumétricas. Revista Árvore. 2002, 26(3), 321-328. https://doi.org/10.1590/S0100-67622002000300007

LEITE, M.L.M.V., et al. Leaf area estimate of Pennisetum glaucum by linear dimensions. Acta Scientiarum. Animal Sciences. $2019,41(1), 1-7$. https://doi.org/10.4025/actascianimsci.v41i1.42808

LEITE, M.L.M.V., et al. Estimativa da área foliar em Urochloa mosambicensis por dimensões lineares. Agropecuária Técnica. 2017, 38(1), 9-16. https://doi.org/10.25066/agrotec.v38i1.32041

LEVINE, D.M., STEPHAN, D.F. and SZABAT, K.A. Estatistic for managers using Microsoft Excel: Global edition. 8th ed. London: Person, 2017.

LUCENA, L.R.R., et al. Estimativa da área foliar em Urochloa mosambicensis por dimensões foliares e imagens digitais. Archivos de Zootecnia. 2018, 66(253), 141-150.

MALAGI, G., et al. Método não destrutivo para determinação da área foliar da videira, cultivar BRS-Violeta. Revista Brasileira de Fruticultura. 2010, 32(4), 1250-1254. https://doi.org/10.1590/\$0100-29452011005000005

MATSUURA, H., PORTO, D. and FETT-NETO, A., 2013. Bioactive alkaloids from South American Psychotria and related Rubiaceae. In: K. RAMAWAT and J. MÉRILLON, eds. Natural Products: Phytochemistry, Botany and Metabolism of Alkaloids, Phenolics and Terpenes, Berlin: Springer-Verlag Berlin Heidelberg, pp. 119-147. https://doi.org/10.1007/978-3-642-22144-6

MOTA, C.S., LEITE, H.G. and CANO, M.A.O. Equações para estimar área foliar de folíolos de Acrocomia aculeta. Pesquisa Florestal Brasileira. 2014, 34(79), 217-224. https://doi.org/10.4336/2014.pfb.34.79.684

MOURA, L.T.S. and MARUO, V.M. Aspectos farmacológicos e toxicológicos de Psychotria colorata - Revisão. Revista Cientifica de Medicina Veterinária. 2014, 22(23), 1-16.

OLIVEIRA, R.F., et al. Utilização de modelos alométricos para estimar a área foliar de Talinum triangulare e Talinum paniculatum. Revista Brasileira de Agropecuária Sustentável. 2019, 9(1), 112-119. https://doi.org/10.21206/rbas.v9i1.3861

PADRÓN, R.A.R., et al. Non-destructive models to estimate leaf area on bell pepper crop. Ciência Rural. 2016, 46(11), $1938-1944$. https://doi.org/10.1590/0103-8478cr20151324

PEEL, M.C., FINLAYSON, B.L. and MCMAHON, T.A. Updated world map of the Köppen-Geiger climate classification. Hydrology and Earth System Sciences. 2007, 11, 1633-1644.

PEZZINI, R.V., et al. Models for leaf area estimation in dwarf pigeon pea by leaf dimensions. Bragantia. 2018, 77(2), 221-229.

https://doi.org/10.1590/1678-4499.2017106

POMPELLI, M.F., et al. Allometric models for non-destructive leaf area estimation of Jatropha curcas. Biomass and Bioenergy. $2012,36,77-85$. 
RIBEIRO, J.E.S., BARBOSA, A.J.S. and ALBUQUERQUE, M.B. Leaf area estimate of Erythroxylum simonis Plowman by linear dimensions. Floresta e Ambiente. 2018a, 25(2), 1-7. https://doi.org/10.1590/2179-8087.010817

RIBEIRO, J.E.S., et al. Seasonal variation in gas exchange by plants of Erythroxylum simonis Plowman. Acta Botanica Brasilica. 2018b, 32(2), 287-296. https://doi.org/10.1590/0102-33062017abb0240

RIBEIRO, J.E.S., et al. Estimation of leaf area of Erythroxylum citrifolium from linear leaf dimensions. Bioscience Journal. 2019a, 35(6), 19231931. https://doi.org/10.14393/BJ-v35n6a2019-41743

RIBEIRO, J.E.S., et al. Leaf area estimation for Psychotria carthagenensis and Psychotria hoffmannseggiana as a function of linear leaf dimensions. Acta Scientiarum. Biological Sciences. 2019b, 41(1), 1-8. https://doi.org/10.4025/actascibiolsci.v41i1.43494

RIBEIRO, J.E.S., et al. Non-destructive method for estimating leaf area of Erythroxylum pauferrense (Erythroxylaceae) from linear dimensions of leaf blades. Acta Botanica Mexicana. 2020a, 127, 1-12. https://doi.org/10.21829/abm127.2020.1717

RIBEIRO, J.E.S., et al. Leaf area estimation of Palicourea racemosa (Aubl.) Borhidi from linear measurements. Floresta e Ambiente. 2020b, 27(4), 1-7. https://doi.org/10.1590/2179-8087.010518

RIBEIRO, J.E.S., et al. A non-destructive method for estimating leaf area of Ceiba glaziovii (Kuntze) K. Schum. Floresta. 2020c, 50(1), 1063-1070. https://doi.org/10.5380/rf.v50i1.61088

SARKER, S.K., et al. Developing allometric equations for estimating leaf area and leaf biomass of Artocarpus chaplasha in Raghunandan Hill Reserve, Bangladesh. Southern Forests. 2013, 75(1), 51-57. https://doi.org/10.2989/20702620.2013.773601

SCHMILDT, E.R., et al. Análise comparativa de equações para estimativa da área foliar em cafeeiros. Coffee Science. 2014, 9(2), 155 -167.

SILVA, S.F., et al. Modelos alométricos para estimativa da área foliar de boldo pelo método não destrutivo. Revista Agrarian. 2017, 10(37), 193198. https://doi.org/10.30612/agrarian.v10i37.2911

SKIRYCZ, A., et al. Medicinal Bioprospecting of the Amazon Rainforest: A Modern Eldorado? Trends in Biotechnology. 2016, 34(10), 781-790. https://doi.org/10.1016/j.tibtech.2016.03.006

SOUSA, L.F., et al. Método prático e eficiente para estimar a área foliar de gramíneas forrageiras tropicais. Archivos de Zootecnia. 2015, 64(245), 83-85. https://doi.org/10.21071/az.v64i245.380

SOUZA, R.K.D., MENDONÇA, A.C.A.M. and SILVA, M.A.P. Ethnobotanical, phytochemical and pharmacological aspects Rubiaceae species in Brazil. Revista Cubana de Plantas Medicinales. 2013, 18(1), 140-156.

SPANN, T.M. and HEEREMA, R.J. A simple method for non-destructive estimation of total shoot leaf area in tree fruit crops. Scientia Horticulturae. 2010, 125(3), 528-533. https://doi.org/10.1016/j.scienta.2010.04.033

TARTAGLIA, F.L., et al. Non-destructive models for leaf area determination in canola. Revista Brasileira de Engenharia Agricola e Ambiental. 2016, 20(6), 551-556. https://doi.org/10.1590/1807-1929/agriambi.v20n6p551-556

TAYLOR, C.M., CAMPOS, M.T.V.A. and ZAPPI, D. Flora Da Reserva Ducke, Amazonas, Brasil: Rubiaceae. Rodriguesia. 2007, 56(86), 189-204.

TOEBE, M., et al. Leaf area estimation in triticale by leaf dimensions. Revista Brasileira de Ciências Agrárias. 2019, 14(2), 1-9. https://doi.org/10.5039/agraria.v14i2a5656

VICENTINI, A.R., et al., 2016. Plantas da família Rubiaceae úteis ao tratamento de enfermidades veterinárias. In: U.R. VIANNA, et al., eds. Tópicos especiais em ciência animal V. Alegre: CAUFES, pp. 149-162.

WILLMOTT, C.J. On the validation of models. Physical Geography. 1981, 2(2), 184-194. https://doi.org/10.1080/02723646.1981.10642213

ZAPPI, D.C., et al. Growing knowledge: An overview of seed plant diversity in Brazil. Rodriguesia. 2015, 66(4), 1085-1113.

https://doi.org/10.1590/2175-7860201566411

ZHANG, L. and PAN, L. Allometric models for leaf area estimation across different leaf-age groups of evergreen broadleaved trees in a subtropical forest. Photosynthetica. 2011, 49(2), 219-226. https://doi.org/10.1007/s11099-011-0027-x

Received: 10 April 2020 | Accepted: 6 July 2020 | Published: 29 December 2021

This is an Open Access article distributed under the terms of the Creative Commons Attribution License, which permits unrestricted use, distribution, and reproduction in any medium, provided the original work is properly cited. 